\title{
PREDATION AS A SELECTION FACTOR IN THE MATING STRATEGY OF THE JUMPING SPIDER PHIDIPPUS JOHNSONI (SALTICIDAE, ARANEAE)
}

\author{
BY R. R. JACKSON* \\ Department of Zoology, University of California \\ Berkeley, California 94720
}

\section{INTRODUCTION}

Predation risks are often considered to be a major selection pressure related to the courtship and mating behavior of animals (Emlen, 1973; Morris, 1956; Richards, 1927; Strong, 1973). The importance of this factor in the mating strategy of a salticid spider, Phidippus johnsoni (Peckham and Peckham), will be considered here. In this species, each individual male has at his disposal three alternative mating tactics (Jackson, 1977). The one used depends on the female's maturity and whether she is inside or outside her nest. Nests are silk structures that the spider constructs under rocks and in other rather dimly lighted locations. These are occupied during inclement weather, at night, during molting and oviposition, and at other times. When the male encounters an adult female outside her nest, he performs a form of visual courtship (type 1), consisting of various postures and movements performed in front of the facing female. A form of non-visual courtship (type 2) is employed when the female is encountered inside her nest, consisting of various forms of shaking and plucking on the silk of the nest. If the female is a subadult, the male may construct a second chamber on her nest and cohabit until she matures. Observations will be presented, implicating certain spiders of the family Gnaphosidae as predators of $P$. johnsoni. These incidences of predation occur while the salticids are at their nests and during courtship.

$P$. johnsoni is a common, euryecious salticid species in western North America. Often other organisms are found associated with nests of this species, both ones that are occupied by P. john-

* Present address: North Carolina Department of Mental Health Research, Box 7532, Raleigh, North Carolina 27611

Manuscript received by the editor February 10, 1977 
soni at the time and ones that are not. Various gnaphosid species are among the most frequent nest associates. Occasionally dead P. johnsoni are found inside their nests. On two occasions, both in the Wind River Range of the Rocky Mountains, a gnaphosid, Drassodes neglectus (Keys), was found inside a nest with a dead $P$. johnsoni female. In each case, the salticid was dry, had ruptures in the cuticle that resembled fang wounds, and had the appearance of having been consumed by another spider. In one case, the nest contained a $P$.johnsoni egg case. The silk around the eggs had been pulled away, but the eggs had not been eaten. $P$. johnsoni tend to be 10 to $12 \mathrm{~mm}$ in length, and the gnaphosids were of comparable size. These observations suggested that large gnaphosids prey upon $P$. johnsoni in their nests and perhaps consume the eggs as well. Further observations were carried out in the laboratory, using another gnaphosid species, Herpyllus hesperolus (Chamberlin). This species was a common nest associate of $P$. johnsoni in the Coastal Range of California, which was more accessible from my laboratory in Berkeley.

\section{METHODS}

Three sets of observations were carried out: $H$. hesperolus encountering $P$. johnsoni inside their nests, $P$. johnsoni males encountering $H$. hesperolus occupying the nests of $P$. johnsoni females, and $P$. johnsoni males encountering empty nests of both $P$. johnsoni females and $H$. hesperolus. The latter were included in order to determine whether $P$. johnsoni males can discriminate between the two types of nests.

Both the salticids and the gnaphosids were collected from habitats near the San Francisco Bay in California. They were maintained individually in $10 \mathrm{~cm}$ long plastic cages, built according to the design described by Jackson (1974), that provided a continual supply of house flies (Musca domestica) and moisture. Both mature and immature gnaphosids were used. Although $P$. johnsoni almost always constructed nests during the first day of occupancy of their cage, the gnaphosids built much less frequently, primarily just before molting. Each spider was used in only one observation, except for the paired observations on each male in the nest discrimination experiment; and each time the spider (and nest) used was chosen randomly, using a random 
numbers table. All observations were made between one and four hours after the lights came on in the laboratory.

\section{INTERACTIONS BETWEEN HERPYLLUS HESPEROLUS AND PHIDIPPUS JOHNSONI FEMALES INSIDE THEIR NESTS}

After oviposition, P. johnsoni females tend to remain in their nests with their eggs; and each $P$. johnsoni in this set of observations had eggs in her nest. Observation began when a $H$. hesperolus was taken from its cage and introduced through a hole in the cage of the $P$. johnsoni. Once the $H$. hesperolus touched the nest, observation continued for $15 \mathrm{~min}$.

During one of the five observations, the $P$. johnsoni slowly departed her nest and approached the gnaphosid that was walking past the nest, approximately $2 \mathrm{~cm}$ away. When $1 \mathrm{~cm}$ from the $H$. hesperolus, the $P$. johnsoni leaped on the gnaphosid and subsequently consumed it. The $H$. hesperolus was $8 \mathrm{~mm}$, and the $P$. johnsoni was $11 \mathrm{~mm}$. The other four gnaphosids had body lengths greater than that of the salticids, approximately $15 \mathrm{~mm}$ compared to 10 to $11 \mathrm{~mm}$ in each case. In each of these observations, the $H$. hesperolus walked onto the nest, and the $P$. johnsoni responded with various behavioral elements that have been previously described in detail for interactions between conspecific males and females at nests (Jackson, 1976). These will be briefly described again here.

Pull on Nest. With the tarsi of her first pair of legs in contact with the inner dorsal surface of the nest the female moves her legs ventrally, pulling the dorsal layer of silk until it contacts the ventral layer.

Bump. The female rapidly extends her legs, causing her cephalothorax to hit the inner dorsal nest surface.

Stab. With her tarsi oriented toward the silk, the female rapidly moves her first pair of legs ventrally. As her tarsi hit the silk, pin-point bulges are made temporarily in the silk.

Strike. The female's elevated first pair of legs are rapidly moved forward and downward, such that the tarsi contact the substrate or the other spider. This behavior was performed with the $P$. johnsoni standing in the nest door, facing outward. Doors are slit-shaped openings in the nest through which the spider enters and departs. 
All four $P$. johnsoni pulled the nest and struck at the gnaphosids. One bumped and another stabbed. Each $P$. johnsoni also walked and turned frequently inside the nest. In three cases, the $H$. hesperolus ran away from the nest after the P. johnsoni struck. In one case, this was after $3 \mathrm{~min}$ in contact with the nest; contact was for between 15 and $30 \mathrm{sec}$ in the other two cases. For the remainder of the observation period, in each of these cases, the $P$. johnsoni remained inside the nest and the $H$. hesperolus remained at the other side of the cage.

During one observation, the $H$. hesperolus killed and consumed the $P$. johnsoni after $18 \mathrm{~min}$ on the nest. Intermittently, the gnaphosid inserted its fangs into the silk and pulled on the nest by raising its cephalothorax. Eventually, a hole was torn through the nest. The $P$. johnsoni repeatedly struck at the gnaphosid through the hole. Suddenly, the $P$. johnsoni walked rapidly through the nest, with the $H$. hesperolus following a parallel path on the outer nest surface. Arriving at the nest door, the P. johnsoni began to depart the nest, but at the moment when its anterior cephalothorax was only barely out the nest door, the $H$. hesperolus leaped from the top of the nest and hit at the carapace of the $P$. johnsoni with its extended fangs. With its body and legs arched over the $P$. johnsoni, the $H$. hesperolus made repeated predatory attacks, consisting of rapidly and briefly lowering its cephalothorax, with fangs open, making contact with the carapace of its victim. The $P$. johnsoni made several strikes at the enveloping $H$. hesperolus, but soon it became relatively immobile, with its forelegs raised. After $30 \mathrm{sec}$, the P. johnsoni was motionless, presumably dead or paralyzed. The $H$. hesperolus pulled with its fangs inserted in the silk in the vicinity of the door, eventually ripping the nest open somewhat. Aproximately $1 \mathrm{~min}$ later, the gnaphosid inserted its fangs into the prey's carapace near the junction of the legs and began to feed.

INTERACTIONS BETWEEN PHIDIPPUS JOHNSONI MALES AND HERPYLLUS HESPEROLUS THAT OCCUPY NESTS OF PHIDIPPUS JOHNSONI FEMALES

P. johnsoni females with eggs were forced from their nests. When $H$ hesperolus were placed in the cages, they soon entered and remained inside the nests with the eggs. The next day a $P$. 
johnsoni male was introduced through a hole in the cage. Once the $P$. johnsoni responded to the $H$. hesperolus, observation was continued for $15 \mathrm{~min}$. In six of the seven observations, the $P$. johnsoni touched the nest, whereupon he began to perform type 2 courtship. Since the elements of this type of courtship have been described in detail elsewhere (Jackson, 1976), only brief descriptions of the major elements will be provided here. Probe. The first pair of legs are moved alternately forward and backward, with the tarsi in contact with the nest.

Vibrate. The tarsi of the first pair of legs are always in contact with the silk; the other legs may or may not contact the nest. A series of extremely rapid, low amplitude, dorsal-ventral movements are performed, which have the appearance of a sudden, faint blurring of the spider and the silk in his vicinity.

Grip Vibrate. The spider vibrates while his fangs are inserted into the silk.

Tug. While gripping the silk with his fangs, the spider moves his cephalothorax alternately dorsally and ventrally, over a distance of a few millimeters.

Since the result of each interaction was different, each will be related briefly.

1. As the P. johnsoni courted, the $H$. hesperolus departed by the opposite door and ran away.

2. The $H$. hesperolus remained inactive as the $P$. johnsoni courted. After the male entered the nest, the gnaphosid departed by the opposite door and ran away.

3. The P. johnsoni entered the nest after courting, with the $H$. hesperolus remaining mostly inactive. Once inside the nest, the gnaphosid began to walk, whereupon the P. johnsoni departed the nest and backed away. When $3 \mathrm{~cm}$ from the nest, the $P$. johnsoni turned $180^{\circ}$ and ran away.

4. As the P. johnsoni probed at the nest door, the H. hesperolus approached, whereupon the $P$. johnsoni backed away $1 \mathrm{~cm}$. For one min the two spiders stood motionless, facing each other, the gnaphosid partly out the nest door. Suddenly, the P. johnsoni turned $180^{\circ}$ and ran, with the $H$. hesperolus making a brief dash toward the male, covering a distance of $1 \mathrm{~cm}$ before stopping then returning to the nest.

5. As the $P$. johnsoni courted on the nest, the $H$. hesperolus began to walk and turn actively inside the nest. When the $P$. 
johnsoni suddenly began to run, the $H$. hesperolus ran out the door and onto the nest, circled the $P$. johnsoni from behind, and arched its body and legs over the facing salticid. The $P$. johnsoni struck repeatedly, and the gnaphosid's fangs were extended. As the P. johnsoni slowly backed off the nest, with its first pair of legs raised, the $H$. hesperolus slowly followed, with arched body, until reaching the edge of the nest. When $6 \mathrm{~cm}$ from the motionless gnaphosid on the nest, the P. johnsoni turned $180^{\circ}$ and ran away.

6. As the P. johnsoni courted at one door, the $H$. hesperolus departed from the opposite door and ran across the nest toward the salticid. Simultaneously, the $P$. johnsoni turned $180^{\circ}$ and ran. The $H$. hesperolus overtook the salticid $1 \mathrm{~cm}$ from the nest, circled its victim, with its body arched, and repeatedly hit the salticid with its extended fangs. After standing with its first pair of legs raised for approximately $30 \mathrm{sec}$, the P. johnsoni became immobile, whereupon the $H$. hesperolus inserted its fangs into the side of the carapace and fed.

In a related species, Herpyllus blackwalli, Bristowe (1958) noted that the fangs are usually buried at the junction of the legs on the side of the prey, consistent with the present observations on $H$. hesperolus. He described the predatory behavior of another gnaphosid, Drassodes lapidosus, in great detail, noting the extremely rapid speed with which the spider moved, arching of the body, and circling the prey. In this species, a band of silk is laid over the prey's legs as the predator circles, something not witnessed for $H$. hesperolus. Another point of interest is that in Bristowe's observations, D. lapidosus preyed, in the laboratory, on a number of other spider species of comparable size, although he did not stage interactions with salticids. Remember that the spiders found with dead P. johnsoni in the field were a species of Drassodes.

During the observation in which the $P$. johnsoni did not touch the nest, the $H$. hesperolus was standing in the nest door, facing outward, apparently motionless. The $P$. johnsoni faced the $H$. hesperolus, while $7 \mathrm{~cm}$ away, and slowly approached. When $3 \mathrm{~cm}$ away, the $P$. johnsoni began to back slowly; and when 5 $\mathrm{cm}$ away, a $180^{\circ}$ turn was made, then the $P$. johnsoni walked rapidly away. A possible interpretation is that the $P$. johnsoni 
recognized the gnaphosid visually, since salticids are known to have highly developed visual abilities (Land, 1972).

Incidentally, after these observations, the gnaphosids were kept for one week in the cages with the P. johnsoni nests and eggs. However, the eggs remained undamaged, lending no support to the hypothesis that gnaphosids prey on P. johnsoni eggs.

\section{NeST DisCRIMINATION}

Each $P$. johnsoni male used in these observations was exposed to an empty nest of a $P$. johnsoni female and an empty $H$. hesperolus nest on successive days. Half were exposed to P. johnsoni nests first, the other half were exposed to $H$. hesperolus nests first, and the spiders were assigned to the two groups randomly. On the day before the observations, nest occupants were removed. No nests contained eggs. The nests of $H$. hesperolus were similar in shape and size to the nests of P. johnsoni; but they differed substantially in silk texture; and they were more transparent. Each nest was used in only one test. The P. johnsoni male was introduced into the cage through a hole, and observation continued for $15 \mathrm{~min}$ after the spider touched the nest.

During both type 1 and type 2 courtship, as well as during conspecific aggressive interactions, the abdomens of P. johnsoni males twitch in a characteristic manner (Jackson, 1976), that is not seen in other contexts. The abdomen of each male twitched while he was on the empty nest of a P. johnsoni female, but not while he was at the nest of a $H$. hesperolus (McNemar, $\mathrm{X}^{2}=4.1667, \mathrm{P}<0.05$ ). In addition, each male performed two elements of type 2 courtship, probing and tugging, while at the empty $P$. johnsoni nest. Two males vibrated at the $P$. johnsoni nests, and none vibrated at the $H$. hesperolus nests; however, these frequencies were not significantly different. Males of other species of spiders are reported to show elements of courtship behavior when they touch the silk of conspecific fernales (Dondale and Hegdekar, 1973; Hollander, et al., 1973; Kaston, 1936).

The $P$. johnsoni males remained on P. johnsoni nests for longer time periods than on $H$. hesperolus nests (Table 1) (Wilcoxon, one tailed test $\mathrm{P}<0.05$ ). Courtship at the empty $P$. johnsoni nests lasted 1 to $7 \mathrm{~min}$. Three males entered the $P$. johnsoni nests. Two of these also entered the $H$. hesperolus nests, these 
Table 1. Time (min) that six Phidippus johnsoni males remained in contact with empty nests, during $15 \mathrm{~min}$ tests. See text for further details.

Male

\begin{tabular}{llllll}
\multicolumn{7}{c}{ Male } \\
2 & 3 & 4 & 5 & 6 & Mean
\end{tabular}

$\begin{array}{llllllll}\text { Type Phidippus johnsoni } & 15 & 7 & 3 & 3 & 2 & 11 & 6.83\end{array}$ of

$\begin{array}{llllllll}\text { Nest Herpyllus hesperolus } & 0.5 & 0.5 & 0.25 & 0.5 & 12 & 2.46\end{array}$

accounting for the two longer residences at gnaphosid nests (Table 1). Inside nests, the spiders alternately groomed, walked about, and remained inactive.

Evidently, $P$. johnsoni males discriminate empty nests built by conspecific females from those built by $H$. hesperolus. Upon encountering gnaphosid nests, they did not court, and usually they remained only briefly.

\section{DISCUSSION}

There is little information available concerning the predators of P. johnsoni. Pompilid wasps are known to take other Phidippus species as larval food (Dorris, 1970; Kaston, 1948; Kurczewski and Kurczewski, 1968; Muma and Jeffers, 1945). Once an acroserid fly pupated from a $P$. johnsoni I collected, and acroserids are know to parasitize other Phidippus (Evert Schlinger, personal communication). No doubt there are many predators of $P$. johnsoni for which there are simply no published reports. Reports of the stomach contents of vertebrates are generally of little use in determining the predators of particular spider species or groups, since the spiders are not identified.

Almost universally, $P$. johnsoni males have bright red abdomens. Although the abdomens of immatures and adult females may be dully marked, in many cases they are bright red, orange, or gold. In the laboratory and at exposed locations in the field, such as on the surface of rocks, these spiders tend to be rather conspicuous. There is no evidence that their coloration is aposematic, although information concerning this is limited. They 
do not taste bitter or noxious to humans (personal observation). When standing motionless on the ground, P. johnsoni tend to be rather inconspicuous, and their coloration may contribute to their crypticity in these circumstances, since many plants close to the ground have brightly colored leaves of size, shape, and color comparable to the abdomen of a P. johnsoni. In addition, since there is evidence that salticids possess color vision (Kaestner, 1950), the abdominal markings may have a communicatory function during type 1 courtship.

Although it has frequently been suggested that during animal courtship and mating the participating individuals are exposed to greater predation than at other times, data to support this contention are rare. Schaller (1972) observed an African lion prey on a courting reedbuck. Predators (Walker, 1964) and parasitoids (Cade, 1975) of some Orthoptera are attracted to male calling songs. The swarming flights of some Diptera, which can be interpreted as courtship, may be attended by heavy predation (Downes, 1969; Syrjamaki, 1966). Observations of this sort at least demonstrate that predation occurs on courting animals, but they are not sufficient to show that predation risks are elevated by courtship and mating.

However, the arguments suggesting this hypothesis are rather convincing. Often it has been argued or implied that a mating or, especially, a courting individual is more conspicuous to predators (Emlen, 1973; Morris, 1956; Platnick, 1971; Richards, 1927). During type 1 courtship, P. johnsoni males tended to be highly conspicuous to human observers, while they gestured with their forelegs and danced in front of females. When provided vegetation and rocks, courting and mating pairs showed no tendency to seek cover (Jackson, 1976), courting and copulating sometimes on the tip of a grass blade or the top of a rock. Species that remain relatively motionless during copulation may reduce their conspicuousness; however, copulating pairs of $P$. johnsoni were not motionless. While standing on the female's dorsal surface, the male applied his paired copulatory organs, on the pedipalpi, one at a time to the female's copulatory openings on the ventral side of her rotated abdomen. In addition to the movements involved in switching palps, the male engaged intermittently in postmount courtship, consisting of various stroking and tapping motions (Jackson, 1976). 
Two additional factors may be important in increasing the predation risks of courting and mating animals. In many species, a pair in copula probably finds it more difficult than usual to escape a predator, given that it has been detected. The other factor is that courtship and mating may be rather demanding tasks for the nervous systems of the participants. This may decrease the probability that the participants will detect the approach of a predator and respond in time to escape. Casual observations on $P$. johnsoni indicated that, when a pair was involved in courtship or mating, they were less responsive to movements of the observer. This was especially true of males.

It will be predicted that predation presents a greater risk to $P$. johnsoni courting and mating outside nests, compared to those courting and mating at nests. This is part of a more general hypothesis that individuals inside nests are subject to less predation than ones outside nests. The predicted safety is relative, not absolute, since the data presented here implicate certain large gnaphosid spiders as predators on P. johnsoni in their nests. Occupancy by $H$. hesperolus of the nests of $P$. johnsoni females and subsequent predation on courting $P$. johnsoni males might be a case of aggressive mimicry (Wickler, 1968), in a limited sense. It would be of much interest to verify that this behavior occurs in the field. Also, it would be of value to attempt to evaluate whether this particular advantage to the gnaphosid is great enough to constitute a significant selection pressure favoring occupancy of $P$. johnsoni nests. Other factors are certainly possible, since organisms such as isopods and anystid mites also occupy $P$. johnsoni nests, and for these the predatory function is very unlikely. In considering the importance of this type of predation for P. johnsoni males, it should be noted that the proportion of $P$. johnsoni nests, in the field, occupied by large gnaphosids is less than one per cent (unpublished data). In addition, males evidently discriminate between $P$. johnsoni and $H$. hesperolus nests.

In conclusion, the following are some ways in which the spider's nest may provide relative safety from predation:

1. The silk of the nest may form a physical barrier between the occupant and the predator.

2. The silk of the nest may provide a sensory barrier, both visual and chemotatic, between the occupant and the predator. Preda- 
tors not adapted to respond to the nest per se may fail to detect the occupant.

3. The nest may provide the occupant with an early-warning device, in effect forming an extension of the spider's tactile sensory system.

4. The nest may put the occupant in a highly defendable position with respect to many predators. Usually there are only two nest doors. This may be the only or easiest way for many predators to gain access to the occupant. Some of the responses shown by females to courting males, such as pulling the door and striking, are apparently effective defense against some predators. Such behavior was used during the interactions with gnaphosids; and in the majority of cases, the P. johnsoni survived the encounter with the predator.

\section{SUMMARY}

P. johnsoni males may court and mate with females either inside or outside their nests, employing a different type of courtship in each circumstance. Although predation probably presents a greater risk to pairs courting and mating outside rather than inside nests, the difference is evidently relative, not absolute. Large gnaphosid spiders were found to occupy P. johnsoni nests containing dead $P$. johnsoni in the field. Laboratory observations implicate the gnaphosid spider Herpyllus hesperolus as a predator of $P$. johnsoni females while they occupy their nests. Other observations implicate $H$. hesperolus as a predator of $P$. johnsoni males that court at the nests of $P$. johnsoni females occupied by $H$. hesperolus. $P$. johnsoni can discriminate between empty $P$. johnsoni nests and empty $H$. hesperolus nests, courting at the former and remaining only briefly at the latter.

\section{ACKNOWLEDGMENTS}

Roy L. Caldwell and Evert I. Schlinger are gratefully acknowledged for their assistance during all phases of this work. I thank Charles Griswold for identifying the gnaphosid spiders and for his comments on the manuscript. I also wish to thank Peter Witt for his comments on the manuscript and Rubenia Daniels for typing the manuscript. This work was supported in part by a NSF predoctoral fellowship. 


\section{REFERENCES}

Bristowe, W. S.: The World of Spiders, 304 pp. London, Collins 1958.

CADE, W.: Acoustically orienting parasitoids: fly phonotaxis to cricket song. Science 190: 1312-1313 (1975).

Dondale, C. D. and B. M. Hegdekar: A contact sex pheromone in Pardosa lapidicina Emerton (Araneae: Lycosidae). Can J. Zool. 51: 400-401 (1973).

Dorris, P. R.: Spiders collected from mud-dauber nests in Mississippi. J. Kansas Ent. Soc. 43: 10-11 (1970).

Downes, J. A.: The swarming and mating flight of Diptera. Ann. Rev. Ent. 14: 271-298 (1969).

EMLen, J. M.: Ecology: an evolutionary approach, 493 pp. Reading, Mass.: Addison-Wesley 1973.

Hollander, J. den, $\cdot$ H. Dijkstra, H. Alleman and L. Vlijm.: Courtship behaviour as species barrier in the Pardosa pullata group (Araneae: Lycosidae). Tijdsch. Ent. 116: 1-22 (1973).

JACKSON, R. R.: Rearing methods for spiders. J. Arachnol. 2: 53-56 (1974).

JACKSON, R. R.: The evolution of courtship and mating tactics in a jumping spider, Phidippus johnsoni. Ph.D. Thesis, University of California, Berkeley (1976).

JACKsON, R. R.: Courtship versatility in the jumping spider, Phidippus johnsoni (Peckham and Peckham) (Salticidae: Araneae) Anim. Behav. (in press) (1977).

Kaestner, A.: Reaktion der Hupfspinnen (Salticidae) auf unbewegte farblose und farbige Gesichtsreize. Zool. Beitr. 1: 12-50 (1950).

Kaston, B. J.: The senses involved in the courtship of some vagabond spiders. Ent. Amer. 16: 97-167 (1936).

Kaston, B. J.: Spiders of Connecticut. Conn. State Geol. and Natur. Hist. Survey Bull 70: 1-874, (1948).

Kurczewski, F. E. And E. J. Kurczewski: Host records for some North American Pompilidae (Hymenoptera) with a discussion of factors in prey selection. J. Kansas Ent. Soc. 41: 1-33 (1968).

LAND, M. F.: Mechanisms of orientation and pattern recognition by jumping spiders (Salticidae). In: Information Processing in the Visual System of Arthropods (R. Wehner, ed.), pp. 231-247. Berlin, Springer-Verlag 1972.

Morris, D.: The function and causation of courtship ceremonies. In: L'Instinct dans le Comportement des Animaux et de L'Homme (P. Grassé, ed.) pp. 261-287. Paris; Masson et Cie 1956.

Muma, M. H. and W. F. Jeffers: Studies of the prey of several mud-dauber wasps. Ann. Ent. Soc. Amer. 38: 245-255 (1945).

Platnick, N.:The evolution of courtship behaviour in spiders. Bull. Brit. Arachnol. Soc. 2: 40-47 (1971).

Richards, O. W.: Sexual selection and allied problems in the insects. Biol. Rev. 2: 298-364 (1927).

Schaller, G. B.: The Serengeti Lion: A Study of Predator-Prey Relations, 480 pp. Chicago: The University of Chicago Press 1972.

Strong, D. R., JR.: Amphipod amplexus, the significance of ecotypic variation. Ecology 54: 1383-1388 (1973).

SyrJamaki, J.: Dusk swarming of Chironomus pseudothummi Strenzke (Dipt. Chironomidae) Ann. Zoo. Fenn. 3: 20-28 (1966). 
WALKER, T. J.: Experimental demonstration of a cat locating orthopteran prey by the prey's calling song. Florida Ent. 47: 163-165 (1964).

Wickler, W.: Mimicry in Plants and Animals, 153 pp. London: Weidenfeld and Nicolson 1968. 


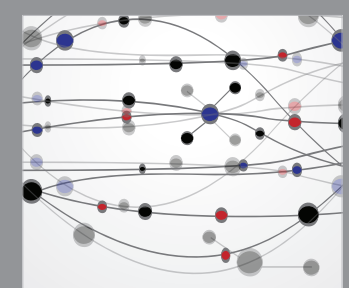

The Scientific World Journal
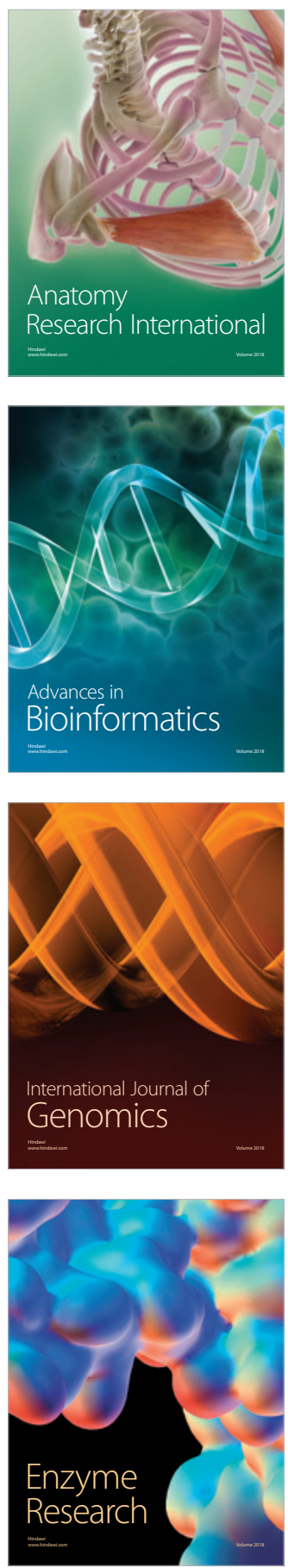
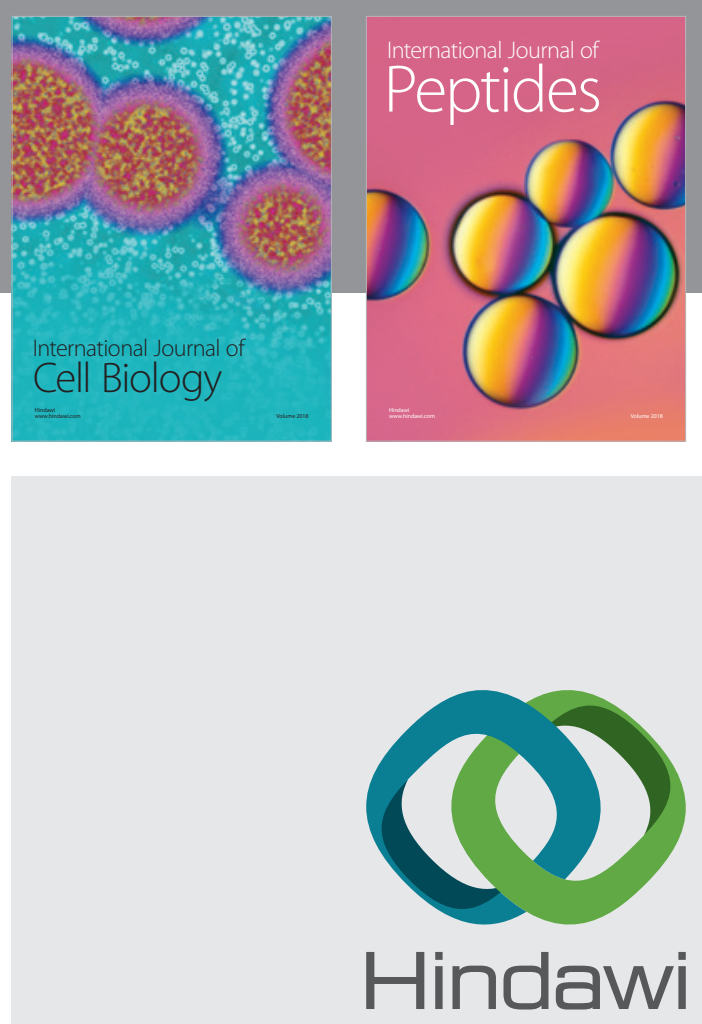

Submit your manuscripts at

www.hindawi.com
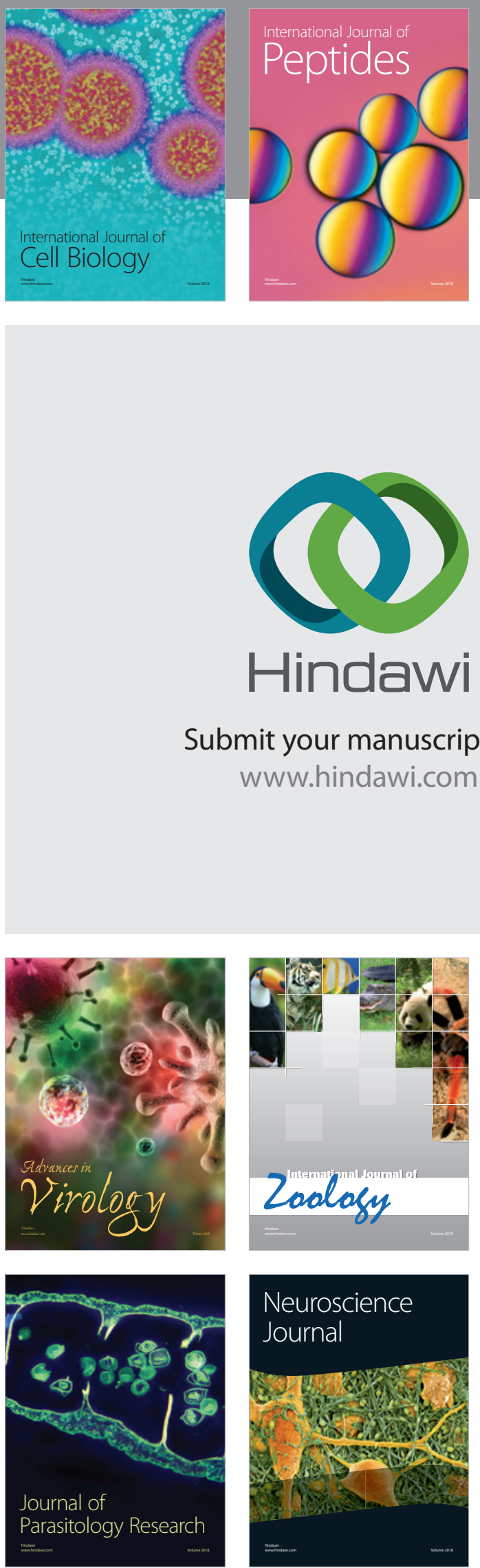
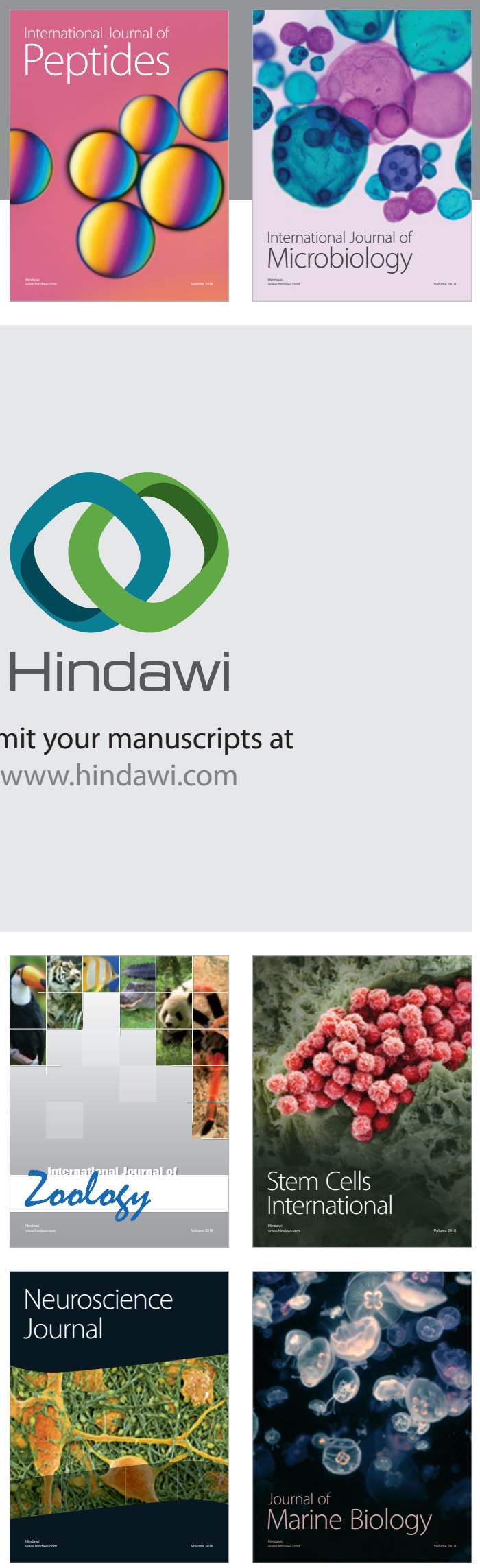
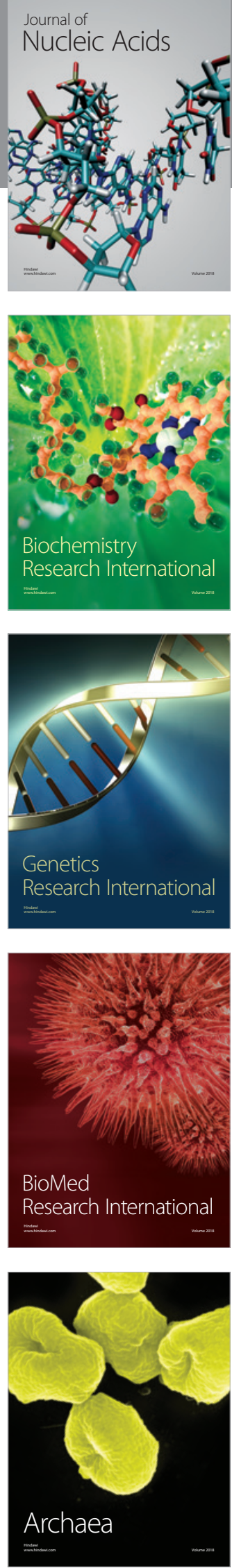